\title{
POWERLIFTING SESSIONS PROMOTE SIGNIFICANT POST-EXERCISE HYPOTENSION
}

\author{
SESSÕES DE POWERLIFTING PROMOVEM HIPOTENSÃO SIGNIFICATIVA PÓS-EXERCÍCIO
}

Original Article

SESIONES DE POWERLIFTING PROMUEVEN HIPOTENSIÓN SIGNIFICATIVA POST-EJERCICIO

\author{
Gustavo Allegretti João,2 \\ (Profissional de Educação Física) \\ Danilo Sales Bocalini' ${ }^{1}$ \\ (Profissional de Educação Física) \\ Daniel Rodriguez' \\ (Profissional de Educação Física) \\ Mario Augusto Charro ${ }^{2}$ \\ (Profissional de Educação Física) \\ Fábio Ceschini ${ }^{1}$ \\ (Profissional de Educação Física) \\ Antônio Martins ${ }^{1}$ \\ (Profissional de Educação Física) \\ Aylton Figueira Junior ${ }^{1}$ \\ (Profissional de Educação Física)
}

1. Universidade São Judas Tadeu, Departamento de Educação Física e Ciências do Envelhecimento, Laboratório de Fisiologia Translacional, São Paulo, SP, Brasil. 2. Faculdades Metropolitanas Unidas - FMU, Laboratório de Fisiologia do exercício e desempenho humano, São Paulo, SP, Brasil.

\section{Correspondência:}

Rua Taquari, 546, Mooca, São Paulo, SP, Brazil. 03166-000.

gustavoallegretti@hotmail.com

\begin{abstract}
Introduction: Powerlifting (PWL) is a worldwide method, frequently used in resistance training programs. However, the relationship between cardiovascular responses and PWL is still unclear in the literature. Objective: To evaluate acute cardiovascular overload and post-exercise hypotension (PEH) after acute powerlifting exercise session in subjects with experience in the modality. Methods: Nine powerlifting athletes ( $34 \pm 5$ years) participated voluntarily in this study. The following exercises were used in the session: squat, bench press and deadlift (95\% of 1 RM, 2 to 5 repetitions). The anthropometric parameters and blood pressure (systolic, diastolic and mean) were evaluated immediately, 5', 10', 30', 60' and 24 hours after the exercise session with a non-invasive automatic pressure monitor. Results: Significant differences $(p<0.05)$ were found between rest and immediately after exercise on systolic (135 \pm 6 vs. $153 \pm 10 \mathrm{mmHg}$ ) and mean (102 \pm 3 vs. $108 \pm 3 \mathrm{mmHg}$ ) blood pressures, but no difference was found at diastolic ( $85 \pm 3$ vs. $85 \pm 4 \mathrm{mmHg}$ ) blood pressure. Additionally, the increase in systolic pressure did not reach values considered as a risk of cardiovascular overload. Significant PEH was found after 60 minutes (systolic: $-12 \pm 12 \%$, diastolic: $-5 \pm 6 \%$ and mean: $-7 \pm 5 \%$ ) and 24 hours after PWL session (systolic: $-5 \pm 4 \%$, diastolic: $-8 \pm 4 \%$ and mean: $-7 \pm 3 \%$ ). Conclusion: Our data demonstrated that a PWL session does not increase systolic blood pressure up to the risk range and promotes PEH after 60 minutes of exercise and that this cardiovascular response persisted after 24 hours post-exertion in powerlifting athletes.
\end{abstract}

Keywords: hypotension; resistance training; exercise.

\section{RESUMO}

Introdução: O levantamento de peso básico ou powerlifting (PWL) é um método frequentemente utilizados em programas de treinamento resistido em todo o mundo. Contudo, a relação das respostas cardiovasculares e PWL ainda não está clara na literatura. Objetivo: Avaliar a sobrecarga cardiovascular aguda e a hipotensão pós-exercício (HPE) depois de uma sessão aguda de exercícios de PWL em indivíduos com experiência na modalidade. Métodos: Nove atletas de PWL (34 \pm 5 anos) participaram voluntariamente deste estudo. Os seguintes exercícios foram realizados na sessão: agachamento, supino e levantamento terra (95\% de 1 RM, 2 a 5 repetições). Os parâmetros antropométricos e a pressão arterial (sistólica, diastólica e média) foram avaliados imediatamente, 5', 10', 30',60' e 24 horas após a sessão de exercício com um monitor automático de pressão não invasivo. Resultados: Foram encontradas diferenças significativas $(p<0,05)$ de pressão sistólica (135 \pm 6 vs. $153 \pm 10 \mathrm{mmHg}$ ) entre o repouso e imediatamente após o exercício e na média (102 \pm 3 vs. $108 \pm 3 \mathrm{mmHg}$ ), porém, não se verificou nenhuma diferença na pressão diastólica ( $85 \pm 3 \mathrm{vs.} 85 \pm 4 \mathrm{mmHg}$ ). Além disso, o aumento da pressão sistólica não atingiu valores considerados risco de sobrecarga cardiovascular. Constatou-se HPE significativa 60 minutos (sistólica: $-12 \pm 12 \%$, diastólica: $-5 \pm 6 \%$ e média: $-7 \pm 5 \%$ ) e 24 horas (sistólica: $-5 \pm$ 4\%, diastólica: $-8 \pm 4 \%$ e média: $-7 \pm 3 \%$ ) depois da sessão de PWL. Conclusão: Nossos dados demonstraram que uma sessão de PWL não aumenta a pressão sistólica a té a faixa de risco e promove HPE após 60 minutos de exercício e que essa resposta cardiovascular persistiu 24 horas pós-esforço nos atletas de powerlifting.

Descritores: hipotensão; treinamento de resistência; exercício.

\section{RESUMEN}

Introducción: El levantamiento de pesas o powerlifting (PWL) es un método de uso frecuente en los programas de entrenamiento de resistencia en todo el mundo. Sin embargo, la relación de las respuestas cardiovasculares y el PWL no está clara en la literatura. Objetivo: Evaluar la sobrecarga cardiovascular aguda y la hipotensión post-ejercicio (HPE) después de una sesión aguda de ejercicios de PWL en individuos con experiencia en el deporte. Métodos: Nueve atletas de PWL (34 \pm 5 años) participaron voluntariamente en este estudio. Los siguientes ejercicios se realizaron en la sesión: sentadilla, press de banca y peso muerto (95\% de 1 RM, 2 a 5 repeticiones). Los parámetros antropométricos y la presión arterial (sistólica, diastólica y media) fueron evaluados inmediatamente, 5, 10', 30', 60'y 24 horas después del entrenamiento, con un monitor de presión automático no invasivo. Resultados: Hubo diferencias significativas $(p<0,05)$ en la presión sistólica entre el descanso e inmediatamente después del ejercicio (135 \pm 6 vs. $153 \pm 10 \mathrm{mmHg})$ y media $(102 \pm 3 \mathrm{vs} .108 \pm 3 \mathrm{mmHg})$, no obstante, no se encontraron diferencias en la presión diastólica $(85 \pm 3 \mathrm{vs} .85 \pm 4 \mathrm{mmHg})$. Además, el aumento de la presión sistólica no alcanzó valores considerados de riesgo de sobrecarga cardiovascular. Seencontró HPE significativa 60 minutos (sistólica: $-12 \pm 12 \%$, diastólica: $-5 \pm 6 \%$ y media: $-7 \pm 5 \%$ ) y 24 horas (sistólica: $-5 \pm 4 \%$, diastólica: $-8 \pm 4 \%$ y media: $-7 \pm 3 \%)$ después de la sesión de PWL. Conclusión: Nuestros datos demuestran que una sesión de PWL no aumenta la presión 
sistólica hasta el rango de riesgo y promueve HPE después de 60 minutos de ejercicio y que la respuesta cardiovascular se mantuvo 24 horas después del ejercicio en atletas de powertlifting.

Descriptores: hipotensión; entrenamiento de resistencia; ejercicio.

\section{INTRODUCTION}

Scientific evidences suggest that regular resistance exercise (RE) is an important strategy to control systemic blood pressure, in both normotensive and hypertensive subjects ${ }^{1,2}$. Among the effects of physical activity on the cardiovascular system, post-exercise hypotension (PEH) has been studied in hypertensive subjects with clinically relevant implications $^{3-5}$. There are several studies utilizing RE to promote BP reduction at acute ${ }^{4,5}$ and chronic ${ }^{6}$ approaches. The mechanisms involved at PEH have been attributed to reduced peripheral vascular resistance, reduced sympathetic activity, and diminished systolic volume and changes in the sensitivity of adrenergic cardiac and endothelial factors ${ }^{7-9}$.

The American College of Sports and Medicine ${ }^{1}$ and the American Heart Association ${ }^{2}$ stated that RE in association with an aerobic based exercise program are efficient to prevent, treat and control the arterial hypertensive, however, the RE and PEH effect still unclear'. In 2015 our group 5 demonstrated that PHE occur independently of exercise intensity without expressed cardiovascular overload during the session, however, to the best of our knowledge, there are few study ${ }^{5,10-12}$ on literature evaluating different manipulation of volume and intensity on RE and the magnitude of PEH.

In this perspective, powerlifting method consists of practice by exercises considered basic, such squat, bench press and deadlift, utilizing load near of maximal repetition test (1RM) $)^{13,14}$. Haslam et al. ${ }^{15}$ shown that higher loadings lead to larger increases in blood pressure and heart rate, additionally, the exercises utilized on powerlifting exercise session is composed of movements can lead to high values of $\mathrm{BP}$ and $\mathrm{HR}^{16-19}$.

According to $\mathrm{ACSM}^{1}$ recommendations high intensity of RE (over $80 \%$ of 1 RM) had been used by athletes, recreational exercisers and fitness center practitioners such strategy to increase of muscular strength, however, there are a gap on literature about influence exercise intensities using load near of $100 \%$ of 1RM. In this way, the purpose of this study was evaluated the acute cardiovascular overload and PEH after acute powerlifting exercise session on subjects with experience PWL modality.

\section{METHODS}

After approval by the Ethics Committee for Human Research of São Judas Tadeu University ( $n^{\circ}$ 90801), nine subject with experience on powerlifting modality participated voluntarily in this study. All study participants signed the Informed Consent Form. The following exclusion criteria was considered: recent hospitalization, symptomatic cardiorespiratory disease or cardiac alterations, metabolic syndrome, renal or hepatic disease, cognitive impairment, progressive or debilitating condition, marked obesity with inability to exercise, involvement by muscle or tendon injury on the last month, being under treatment of infectious disease, using any type of medication that alters the cardiovascular, hormonal and / or metabolic responses, being submitted to a weight loss diet and/or any other medical contraindication to physical exercise. The inclusion criteria were having at least 1 year of experience in weightlifting training.

The exercise program was consisted at one single powerlifting exercise session, utilizing three exercises: squat, bench press and deadlift. For the training session athletes used 95\% of 1RM, with 5 of 2 repetitions in each exercise with 5 minutes of rest. The execution of the exercises was standardized according to the competitive rules of the International Powerlifting Federation. To determine external load all subject performed one repetition maximum (1RM) testing by repeating the methods previously published by our group ${ }^{20}$. All tests were performed with the same examiner present and on the same equipment. The participants were instructed not to perform any other exercise during the period in which the experiment occurred. In each test session and between each exercise, 10 repetitions of the specific exercise were performed to warm-up specific muscles using $50 \%$ of the estimated load (approximating 20\% and $40 \%$ of 1RM). Following a rest of 2-3 minutes, the test began. Four attempts were offered to reach $1 \mathrm{RM}$, a widely accepted indicator of voluntary strength. In the first test set, the subjects were instructed to complete two repetitions. The second test set was performed after a 5 -minute rest, with a greater or smaller load than that was applied in the previous test set. If the attempt was successful, weight was increased in the next set. If the attempt was unsuccessful, weight was reduced in the next set. This procedure was repeated during the third and fourth attempts to clearly identify the load corresponding to $1 \mathrm{RM}$. The load corresponding to 1RM was defined as the weight with which the individual could only complete one correct repetition in a set. No more than five attempts were necessary to reach 1RM with any subject.

The anthropometric evaluation were conducted as previously study of our group ${ }^{13}$. Briefly, the height was measured on a Cardiomed (WCS model) stadiometer, with an accuracy of $115 / 220 \mathrm{~cm}$. The measurement was performed with the cursor at an angle of $90^{\circ}$ with respect to scale, with the patient in the standing position with feet together, and while the subject made contact with the measuring instrument with the posterior surfaces of the heels, occipital bone, and scapula. The subjects were instructed to stay in inspiratory apnea with the top of the head parallel to the ground. Body mass was measured on a Filizola electronic scale (Personal Line Model 150) with a resolution of $100 \mathrm{~g}$ and a maximum capacity of $150 \mathrm{~kg}$. Body composition was determined through skinfold thickness using the Lange Skinfold Caliper (Laffayete Instruments, USA). Fat mass (FM) was determined by equation ( $F M=\%$ Fat $x$ weigth $\div 100$ ) and the lean mass was estimated by the subtraction of fat mass from total body mass.

The systolic blood pressure (SBP), diastolic blood pressure (DBP), mean arterial blood pressure (MBP) (MBP $=\mathrm{DBP}+[\mathrm{SBP}-\mathrm{DBP}] / 3)$ and $H R$ were measured before, during, and immediately after each training session using an automated non-invasive BP monitor (Microlife 3AC11PC, Microlife, Widnau, Switzerland). Heart pressure product (HPP) was evaluated according to the following equation: RPP $=H R^{*}$ SBP. According to previously publication of our group ${ }^{5}$, the measurement was performed after the subjects completed each set (a total of three); the objective of this measurement was to guarantee that BP did not fall during the exercise session. All BP measurements were taken on the left arm. Individual cuffs were labeled with the ranges of arm circumferences. Pre-exercise BP did not exceed 160 and $100 \mathrm{mmHg}$ for SBP and DBP, respectively. During exercise, $\mathrm{HR}$ was continuously measured and recorded on a beat-by-beat basis using a Polar Vantage NV (Polar Electro, Oulu, Finland) HR recorder. Volunteers were also instructed to avoid the Valsalva maneuver during the entire movement, following American College of Sports Medicine guidelines. To evaluate the occurrence of $\mathrm{PEH}, \mathrm{BP}$, and $\mathrm{HR}$ were also measured on rest, in exercise peak (immediately on final of exercise session) and in the sitting position (resting) at 5, 10, 30, 60 minutes and 24 hours after exercise session. To obtain $\mathrm{MVO}_{2}$, we used a mathematical function based on a high correlation between heart pressure product 
and $\mathrm{MVO}_{2}$. The following equation expressed in $\mathrm{mlO}_{2} / 100 \mathrm{gVE} / \mathrm{min}$ were used: $\mathrm{MVO}_{2}=(\mathrm{DP} \times 0.0014)-6.37$.

\section{Statistical analyses}

All statistical analyses were performed using SPSS software ( $v$ 15.0; IBM, Armonk, NY, USA). Analysis of comparisons between groups over the periods was performed with one-way analysis of variance with repeated measures, followed by Kruskal-Wallis or Bonferroni's post-hoc test when appropriate. The D'Agostino-Pearson test was applied to Gaussian distribution analysis. Statistical significance was established at $p<0.05$. Data is expressed as mean \pm standard deviation. Additionally, the magnitude of the training effect was calculated using the mathematical formula that considers the final average the final average value subtracted from the initial average value in relation to the variation of initial mean: [Pre-Post $\mathrm{ES}=$ Posttest mean - Pretest mean / Pretest SD] ${ }^{21}$.

\section{RESULTS}

The anthropometric parameters are described on Table 1. The hemodynamic analysis of powerlifting exercise session at rest, exercise peak and recovery are presented at Figure 1. Significant increase $(p<0.01)$ was observed from rest to exercise peak in SBP (Panel 1A: rest $135 \pm 6 \mathrm{mmHg}$; exercise peak: $153 \pm 10 \mathrm{mmHg}$; $11 \pm 4 \%$ :), MBP (Panel 1C: rest $102 \pm 3 \mathrm{mmHg}$; exercise peak: $108 \pm 3 \mathrm{mmHg}$; $6 \pm 3 \%$ ), HR (Panel 1D: rest $77 \pm 11$; exercise peak: $160 \pm 20$ bpm; $50 \pm 10 \%)$, RPP (Panel 1E: rest: $10442 \pm 1583$ bpm*mmHg; exercise peak $24561 \pm 4040$ bpm*mmHg; $56 \pm 10 \%$ ) and $\mathrm{MVO}_{2}$ (Panel 1F: rest: $8.24 \pm$ $0,73 \mathrm{mlO}_{2} / 100 \mathrm{gVE} / \mathrm{min}$; exercise peak $28.01 \pm 1.88 \mathrm{mlO}_{2} / 100 \mathrm{gVE} / \mathrm{min} ; 69 \pm$ 11\%) but not to DBP (Panel 1B: $85 \pm 3 \mathrm{mmHg}$; exercise peak $85 \pm 4 \mathrm{mmHg}$; $0.99 \pm 5 \%$ ). Additionally, the effect size in relationship rest versus exercise peak was large to SBP (2.65), MBP (2.18), HR (7.5), RPP (8.92), $\mathrm{MVO}_{2}$ (8.92), but small to DBP (0.32).

During recovery, differences were found only on SBP $(122 \pm 9 \mathrm{mmHg})$ and $\mathrm{MBP}(95 \pm 3 \mathrm{mmHg})$ at $60 \mathrm{~min}$ in relation at rest with trivial effect size to both parameters $(-2.11$ and -1.07$)$ respectively. No differences were presented on others parameters.

The $24 \mathrm{~h}$ analyses recovery could be observed at Figure 2 . Statistical reductions ( $p<0.001$ ) were found in all parameters $24 \mathrm{~h}$ after powerlifting exercise session, at SBP (rest $135 \pm 6 \mathrm{mmHg}$; 24h $128 \pm 6 \mathrm{mmHg} ;-5 \pm 3 \%$ ), DBP (rest $84 \pm 3$; $24 \mathrm{~h} 78 \pm 3 \mathrm{mmHg} ;-8 \pm 4 \%$ ), MBP (rest $102 \pm 3 \mathrm{mmHg} ; 24 \mathrm{~h} 95 \pm 3,2 \mathrm{mmHg}$; $-7 \pm 3 \%$ ) on Panel A, and HR (Panel B: rest 77 \pm 3 bpm; $24 \mathrm{~h} 70 \pm 2$ bpm; $-8 \pm 9 \%$ ), RPP (Panel B: rest $10442 \pm 1583$ bpm*mmHg; $24 \mathrm{~h} 9115 \pm 1013$ bpm*mmHg; $-14 \pm 12 \%$ ) and $\mathrm{MVO}_{2}$ (rest: $8.24 \pm 2.27 \mathrm{mlO}_{2} / 100 \mathrm{gVE} / \mathrm{min} ; 24 \mathrm{~h}$ : $6.39 \pm 1.42 \mathrm{mlO}_{2} / 100 \mathrm{gVE} / \mathrm{min} ;-29 \pm 24 \%$ ) on Panel B. In all parameters the effect size of $24 \mathrm{~h}$ post exercise to $\operatorname{SBP}(-1,05), \mathrm{DBP}(-1,97), \operatorname{MBP}(-2,16), \mathrm{HR}$ $(-0,56), \operatorname{RPP}(-0,84), \mathrm{MVO}_{2}(-0,84.7)$. SBP $(-1,05), \operatorname{MBP}(2.18), \operatorname{HR}(7.5), \operatorname{RPP}(8.92)$ and $\mathrm{MVO}_{2}$ (8.92) were trivial.

\section{DISCUSSION}

The major new findings of the present study were 1) the powerlifting training sessions does not promote hemodynamic overload towards to range risk, 2) the exercise session promote decreased on

Table 1. Sample caracteristics.

\begin{tabular}{c|c}
\hline & Mean \pm DP \\
\hline Age (years) & $34 \pm 5$ \\
\hline Bodyweight $(\mathrm{kg})$ & $92 \pm 14$ \\
\hline Stature $(\mathrm{m})$ & $1.75 \pm 7$ \\
\hline Fat body $(\%)$ & $14 \pm 3$ \\
\hline Fat mass $(\mathrm{kg})$ & $13 \pm 4$ \\
\hline Leanmass $(\mathrm{kg})$ & $79 \pm 10$ \\
\hline Experience $(\mathrm{years})$ & $7 \pm 3$ \\
\hline PAS rest (mmHg) & $135 \pm 6$ \\
\hline PAD rest $(\mathrm{mmHg})$ & $84 \pm 3$ \\
\hline Test 1RM squat $(\mathrm{kg})$ & $184 \pm 22$ \\
\hline Test 1RM bench press $(\mathrm{kg})$ & $153 \pm 13$ \\
\hline Test 1RM deadlift $(\mathrm{kg})$ & $202 \pm 30$ \\
\hline
\end{tabular}

values expressed in mean \pm standard deviation.
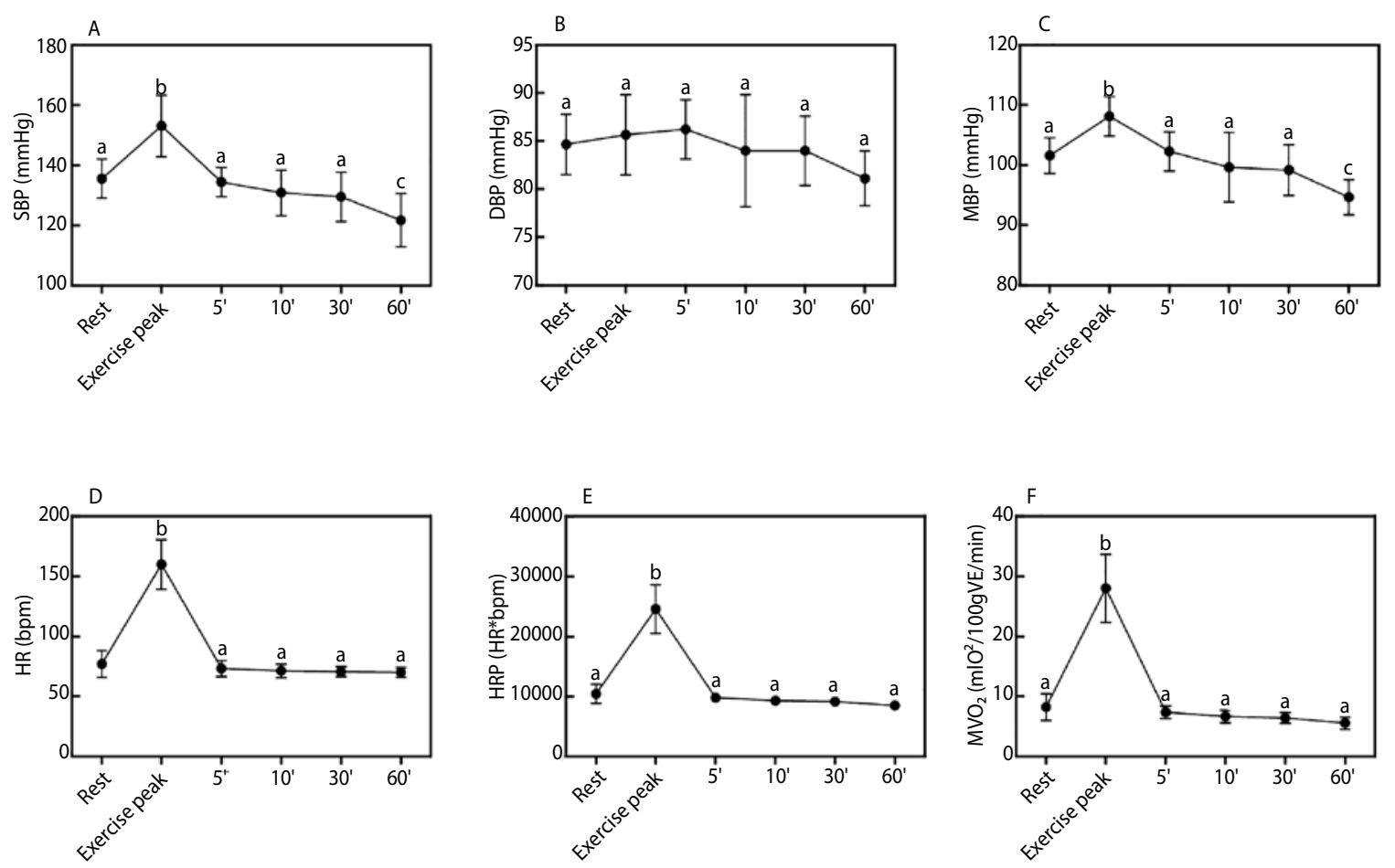

Figure 1. Values expressed as the mean \pm standard error deviation of PHE to Panel A: systolic blood pressure (SBP), Panel B: diastolic blood pressure (DBP), Panel C: mean blood pressure (MBP), Panel D: heart rate (HR), Panel E: rate pressure product (RPP) and Panel E: myocardium oxygen volume $\left(\mathrm{MVO}_{2}\right)$ after powerlifting training session. Different letters indicate statistical differences $(p<0.05)$ to ANOVA repeated measurements. 
SBP after 60 min of exercise session, and 3) the PHE persisted after 24 hours after powerlifting training sessions.

Important information should be address in this study, although had been used very high training intensities (>90\% of 1RM), the exercise session does not promote hemodynamic overload during the practice. Some important consideration should be pointed about this fact, although the powerlift practice is usually done with high intensity, the values of systolic Blood pressure was not high then $(160 \mathrm{mmHg}$ ).

Traditionally, powerlifting training sessions often use small volumes and high intensity could reach $100 \%$ of $1 \mathrm{RM}^{13,14}$, which could lead to a sharp adjustment that provide unique and differentiated hemodynamic responses. There are few studies ${ }^{5,10-12}$ on literature that evaluated the impact of alterations of external load (intensity) on PEH, demonstrating ${ }^{11,12}$ or absence ${ }^{22}$ PHE after load modification. In relationship to training volume, previous studie ${ }^{22-25}$ does not found effect on PHE magnitude after its modification.

In 2015 Cavalcante et al. ${ }^{5}$ demonstrated that PHE occur independently of exercise intensity without expressed cardiovascular overload during the session, however, there are few study ${ }^{5,10-12}$ on literature evaluating different manipulation of volume and intensity on RE and the magnitude of PEH. In this study the PHE were found after 60 min and 24 hour after PWL exercise session just in SBP. Duncan et al. ${ }^{3}$ and Hardy and Tucker ${ }^{26}$ found a reduction in SBP that persisted for at least 1 hour after a RT session and Queiroz et al. ${ }^{4}$ found reduction of SBP after 24 hours after aerobic exercise. Considering the influence of load at PHE, Fisher ${ }^{27}$ studied normotensive and hypertensive women after exercises at $50 \%$ of $1 \mathrm{RM}$ found significant SBP reduction for 60 minutes. Moraes et al. ${ }^{28}$ also analyzed the hypotensive effect of resistance exercise in hypertensive middle-aged men with loads of $60 \%$ of $1 \mathrm{RM}$ significantly reduced SBP, DBP, and MBP, respectively, by an average of 16,12 , and $13 \mathrm{mmHg}$ to pre-hypertensive values. To our knowledge, there is only one study Brandão Rondon et al. ${ }^{9}$ that showed a reduction in SBP, DBP, and MBP for 60 minutes simultaneously.

Though the PHE had been much studied, the mechanisms
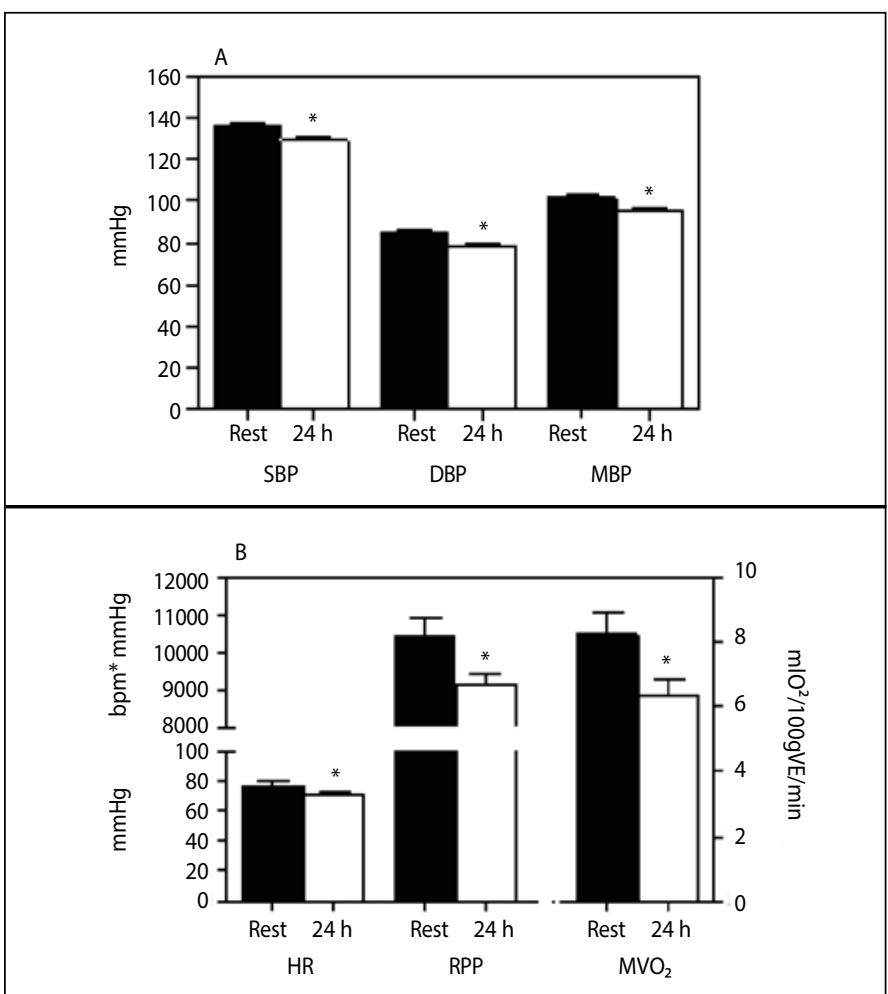

Figure 2. Values expressed as the mean \pm standard error deviation of PHE to Panel A: systolic blood pressure (SBP), diastolic blood pressure (DBP) and mean blood pressure $(\mathrm{MBP})$, Panel $\mathrm{B}$ : heart rate (HR), rate pressure product (RPP) and myocardium oxygen volume $\left(\mathrm{MVO}_{2}\right)$ after powerlifting training session. ${ }^{*} \mathrm{p}<0.01$ indicate statistically significant differences to rest. responsible for decreases in post resistance exercise BP are outside the scope for this study, however, theses have not been completely elucidated in the scientific literature ${ }^{29}$. Previous studies ${ }^{5,6,10}$, suggest that several mechanisms can influence the cardiovascular and PHE behavior. So, overall the hypotensive effect may be associated with factors such as occlusion of the vessels and arteries, cardiac output, stroke volume, autonomic modulation of heart rate through the sympathetic and parasympathetic nerves, in addition to peripheral vascular resistance that can be changed during training ${ }^{30-32}$.

In relation to autonomic modulation evidences indicate that at higher intensities (above 80\%) appears to be a reduction in cardiac output mediated decrease in stroke volume (SV) ${ }^{11}$. The drop in SV would be offset by an increase in HR caused by increased sympathetic activity and parasympathetic reduction in heart. Additionally, the vasodilation mediated by the action of kallikrein system / kinin which also have higher concentrations after $\mathrm{RE}^{28} \mathrm{can}$ be involved on this effect. Simultaneously, other peripheral vasodilators such as nitric oxide, prostaglandins, adenosine, and potassium may also appear to influence the $\mathrm{PHE}^{33,34}$. It is speculated also that the blood lactate concentration interferes with the blood pressure response after exercise ${ }^{35}$. The lactate accumulation could cause reduction in vascular resistance with consequent PHE. In this case, exercises performed with higher intensities would cause increased release of lactate ${ }^{36}$.

According to Negrão et al. ${ }^{30}$ the aspects of training load should be associated with hemodynamic response we should note the concern about the workload, and the percentage of 1 repetition maximum (\% of $1 \mathrm{RM})$, the number of series and number of repetitions, rest interval between series, factors that are associated with pressure changes during and after exercise session. Figueira Júnior et al. ${ }^{6}$ and Fagard ${ }^{36}$ considered the volume of strength training as number of series, repetition number and amount of exercise, are the variables that can promote increases on blood pressure during and post exercise. Another factor important consideration to PHE and its influence should be address to muscle mass involved in exercise and training session. Polito and Farinatti ${ }^{37}$ was not found changes PHE after leg extension exercise in different training models. Similar responses were found by D'Assunção et al. ${ }^{31}$ using exercises with small muscle mass compared large mass.

Therefore, muscle group or larger amount of muscle mass involved during exercise, cannot be the main reasons for changing the hypotensive effect. In this case the powerlifting modality the PHE may be due to the involvement of a larger number of joints in the same movement increase need for blood in the active region, increasing vasodilation, reduce peripheral resistance and favoring $\mathrm{PHE}^{6}$. Studies ${ }^{31,37,38}$ had showed differences on mono and multi-joint exercises. In this case, the exercise performed in this study by powerlifting athlete has multi-joints characteristics associated with large muscle groups, which may have enhanced the hypotensive effect ${ }^{13}$.

Although few studies have evaluated the effects of strength training with high intensity in the cardiovascular response, we noted that the elevation of systolic and diastolic blood pressure increase progressively, reaching higher values in the last repetition, and early fatigue. In general, it can be seen that low intensity and high reps are more elevated blood pressure ${ }^{6,17}$. Muscle mass exerts influence on cardiovascular response, on the other hand, there is still no consensus in the literature on the hypotensive effect. We can observe that when used the same intensity and the same amount in exercises involving larger mass muscle produces significant increase in blood pressure. Furthermore, the Valsalva maneuver may exert influence on the increase hypotensive, the Valsalva maneuver is inevitable with intensity equal to or greater than $80 \%$ of 1 RM. However, in this study, the athletes perform several sets, interspersed with periods of rest between 3-5 minutes which allowed full recovery of systolic pressure, hence its increase in subsequent sets will be higher. 
The hypothesis for PHE on strength training with high intensity for powerlifting practitioner may be related to decreased cardiac output caused by a reduction in stroke volume. The increase in stroke volume is related to an increase in cardiac contractility, which led to gradual decrease in end systolic volume, in other words, greater volume of ventricular filling during diastole. The results obtained in this study may provide relevant information about PHE, the variables possibly related to hypotension mechanisms as sympathetic activity, blood flow, cardiac output and production of nitric oxide have not been evaluated. However, this experience becomes relevant, since it is the first to directly investigate the influence of the intensity of strength training on multi-joints exercises, involving the greatest amount of muscle mass and low number of repetitions, and the response of the PEH effect.

Our study does have some limitations that should be mentioned. First, the mechanisms of hypotension were not investigated in the present study. We did not assess the exercise effects on peripheral vascular resistance as well as sympathetic activity, systolic volume, beta-adrenergic receptors, or endothelial factors. Second, the auscultation method used for assessing blood pressure. This method, while universally used, has limitations compared to invasive methods, such as intra-arterial catheterization; however, all safeguards were taken to ensure that these measures were obtained in a consistent, reliable, and accurate manner. Third, the number of subjects on sample and a lack of control group (not athletes) may be useful to comparative effects.
Thus, it appears that the type of exercise, muscle mass involved, intensity and volume of strength training can be an important factor on cardiovascular response, especially on SBP and DBP post effort. More studies are needed to clarify the influence of RE variables on $\mathrm{PEH}$ in addition to the elucidation of the mechanisms involved in this phenomenon mainly in intense strength training in normotensive and hypertensive subjects.

\section{CONCLUSION}

In summary, the data presented in this study show that PEH effect in powerlifting practitioners after $60 \mathrm{~min}$ and 24 hours after exercise session without promote hemodynamic overload during an exercise session in PWL athletes.

\section{ACKNOWLEDGMENTS}

The authors thanks CAPES (Coordenação de Aperfeiçoamento de Pessoal de Nível Superior) fellowships addressed to João G.A., Rodriguez D. and Ceschini F. The fund providers had no role in decision to publish and preparation of the paper.

All authors have declared there is not any potential conflict of interests concerning this article.

AUTHORS' CONTRIBUTIONS: Each author contributed individually and significantly to the development of the manuscript. GAJ (0000-0002-6338-0798)* and DSB (00000003-3993-8277)* were the main contributors in the drafting of the manuscript. DR (0000-0002-5349-8290)* MAC 0000-0001-8174-2548 and AM (0000-0001-5769-7556)* followed the protocols and the collections. AFJ (0000-0002-6635-8019)* and FC (0000-0001-7829-1184)* evaluated the data from the statistical analysis. DR performed the bibliographic research, reviewed the manuscript and contributed to the study's intellectual concept. *ORCID (Open Researcher and Contributor ID).

\section{REFERENCES}

1. American College of Sports Medicine. American College of Sports Medicine position stand. Progression models in resistance training for healthy adults. Med Sci Sports Exerc. 2009;41(3):687-708.

2. Williams MA, Haskell WL, Ades PA, Amsterdam EA, Bittner V, Franklin BA, et al. Resistance exercise in individuals with and without cardiovascular disease: 2007 update: a scientific statement from the American Heart Association Council on Clinical Cardiology and Council on Nutrition, Physical Activity, and Metabolism. Circulation. 2007;116(5):572-84

3. Duncan MJ, Birch SL, Oxford SW. The effect of exercise intensity on postresistance exercise hypotension in trained men. J Strength Cond Res. 2014;28(6):1706-13.

4. Queiroz AC, Gagliardi JF, Forjaz CL, Rezk CC. Clinic and ambulatory blood pressure responses after resistance exercise. J Strength Cond Res. 2009;23(2):571-8.

5. Cavalcante PA, Rica RL, Evangelista AL, Serra AJ, Figueira A Jr, Pontes FL Jr, et al. Effects of exercise intensity on postexercise hypotension after resistance training session in overweight hypertensive patients. Clin Interv Aging. 2015;10:1487-95.

6. Figueira Júnior AJ, Rodriguez D, Gama EF, Pontes Jr FL, Bocallini DS. Exercise influence on morphological changes in cardiovascular control centers: Integration and adaptation. Rev Bras Ci e Mov. 2013;21(1):166-73.

7. Eysmann SB, Gervino E, Vatner DE, KatzSE, Decker L, Douglas PS. Prolonged exercise alters beta-adrenergic responsiveness in healthy sedentary humans. J Appl Physiol (1985). 1996;80(2):616-22.

8. Kulics JM, Collins HL, DiCarlo SE. Postexercise hypotension is mediated by reductions in sympathetic nerve activity. Am J Physiol. 1999;276(1 Pt 2):H27-32.

9. Brandão Rondon MU, Alves MJ, Braga AM, Teixeira OT, Barretto AC, Krieger EM, et al. Postexercise blood pressure reduction in elderly hypertensive patients. J Am Coll Cardiol. 2002;39(4):676-82.

10. Bentes CM, Costa PB, Neto GR, Costa e Silva GV, de Salles BF, Miranda HL, et al. Hypotensive effects and performance responses between different resistance training intensities and exercise orders in apparently health women. Clin Physiol Funct Imaging. 2015;35(3):185-90.

11. RezkCC, Marrache RC, Tinucci T, Mion D Jr, Forjaz CL. Post-resistance exercise hypotension, hemodynamics, and heart rate variability: influence of exercise intensity. Eur J Appl Physiol. 2006;98(1):105-12.

12. Lizardo, JHF e Simões, HG. Efeitos de diferentes sessões de exercícios resistidos sobre a hipotensão pós-exercício. Rev Bras Fisioter. 2005;9(3): 289-95.

13. João GA, Evangelista AL, Gomes JH, Charro MA, Bocalini DS, Cardozo D, et al. Effect of 16 weeks of periodized resistance training on strength gains of powerlifting athletes JEPonline 2014;17(3):102-9.

14. Pritchard HJ, Morton Rh. Powerlifting: success and failure at the 2012 Oceania and 2013 classic world championships. J Australian Strength Cond 2015;23(6):67-70.

15. Haslam DRS, McCartney N, McKelvie RS, MacDougall JD.Direct measurements of arterial blood pressure during formal weightlifting in cardiac patients. J Cardiopulm Rehabil. 1988;8:213-25.

16. McCartney N. Acute responses to resistance training and safety. Med Sci Sports Exerc. 1999;31(1):31-7.

17. Boroujerdi SS, Rahimi R, Noori SR. Effect of high-versus low-intensity resistance training on post exercise hypotension in male athletes Int Sport Med J 2009;10(2):95-100.

18. MacDougall JD, Tuxen D, Sale DG, Moroz JR, Sutton JR. Arterial blood pressure response to heavy resistance exercise. J Appl Physiol (1985). 1985;58(3):785-90.

19. MacDonald JR. Potential causes, mechanisms, and implications of post exercise hypotension. J Hum Hypertens. 2002;16(4):225-36.

20. Bocalini DS, Portes LA, Ribeiro KJ, Tonicelo R, Rica RL, Pontes Jr FL, et al. Insight for learning and stability of one repetition maximum test in subjects with or without experience on resistance training. Gazz Med Ital Arch per le Sci Med. 2013;172(11):845-51.

21. Rhea MR. Determining the magnitude of treatment effects in strength training research through the use of the effect size. J Strength Cond Res. 2004;18(4):918-20.

22. Faraji H, Bab L, Ardeshiri H. Effects of resistance exercise intensity and volume on post exercise hypotensive responses. Braz J Biomotr 2010;4(1):65-73.

23. Simão R, Fleck SJ, Polito M, Monteiro W, Farinatti P. Effects of resistance training intensity, volume, and session format on the postexercise hypotensive response. J Strength Cond Res. 2005;19(4):853-8.

24. Jones H, George K, Edwards B, Atkinson G. Is the magnitude of acute post-exercise hypotension mediated by exercise intensity or total work done? Eur J Appl Physiol. 2007;102(1):33-40.

25. Keese F, Farinatti P, Pescatello L, Monteiro W. A comparison of the immediate effects of resistance, aerobic, and concurrent exercise on postexercise hypotension. J Strength Cond Res. 2011;25(5):1429-36

26. Hardy DO, Tucker LA. The effects of a single bout of strength training on ambulatory blood pressure levels in 24 mildly hypertensive men. Am J Health Promot. 1998;13(2):69-72.

27. Fisher MM. The effect of resistance exercise on recovery blood pressure in normotensive and borderline hypertensive women. J Strength Cond Res. 2001;15(2):210-6.

28. Moraes MR, Bacurau RF, Ramalho JD, Reis FC, Casarini DE, Chagas JR, et al. Increase in kinins on post-exercise hypotension in normotensive and hypertensive volunteers. Biol Chem. 2007;388(5):533-40.

29. Gomes Anunciação P, Doederlein Polito M. A review on post-exercise hypotension in hypertensive individuals. Arq Bras Cardiol. 2011;96(5):e100-9.

30. Negrão CE, Rodon, MUPB. Exercício físico hipertensão e controle barorreflexo da pressão arterial. Rev Bras Hipertens. 2001;8(1):89-95.

31. D'Assunção W, Daltro M, Simão R, Polito MD, Monteiro W. Resposta cardiovasculares agudas no treinamento de força conduzido em exercícios para grandes e pequenos grupos musculares. Rev Bras Med Esporte. 2007;13(2):118-22.

32. Rocha AC, Moraes-Silva IC, Quinteiro HRG, Sartori M, De Angelis K. Ajustes agudos, subagudos e crônicos da pressão arterial ao exercício resistido. Con Scien Saúde. 2012;11(4):685-90.

33. Goto C, Higashi Y, Kimura M, Noma K, Hara K, Nakagawa K, et al. Effect of different intensities of exercise on endothelium-dependent vasodilation in humans: role of endothelium-dependent nitric oxide and oxidative stress. Circulation. 2003:108(5):530-5.

34. Pescatello LS, Franklin BA, Fagard R, Farquhar WB, Kelley GA, Ray CA; American College of Sports Medicine. American College of Sports Medicine position stand. Exercise and hypertension. Med Sci Sports Exerc. 2004;36(3):533-53.

35. Simões GC, Moreira SR, Kushnick MR, Simões HG, Campbell CS. Postresistance exercise blood pressure reduction is influenced by exercise intensity in type-2 diabetic and nondiabetic individuals. J Strength Cond Res. 2010;24(5):1277-84.

36. Fagard RH. Exercise characteristics and the blood pressure response to dynamic physical training. Med Sci Sports Exerc. 2001;33(Suppl 6):S484-92

37. Polito MD, Farinatti PT. The effects of muscle mass and number of sets during resistance exercise on postexercise hypotension. J Strength Cond Res. 2009;23(8):2351-7.

38. Goldring N, Wiles JD, Coleman DA. The effects of four weeks home-based isometric exercise training on resting blood pressure. Am Col Sports Med. 2012;44(5):S486-S612 